\title{
Kierkegaard's Influence on the Lives of Jan Patocka and Viktor Frankl
}

\author{
Jerry L. Terrill \\ Houston Graduate School of Theology
}

\begin{abstract}
The writings of Soren Kierkegaard provide a theological and philosophical foundation as experienced in the life of a tragic hero and a knight of faith. It will be shown that the ethical dimensions as experienced by Abraham in "Fear and Trembling” provide a core ontology in the lives of Jan Patocka and Viktor Frankl. Jan Parocka developed a phenomenological, Kierkegaardian, existential approach in his writings and lectures that enabled him to undergo his interrogations by the Czech communist secret police. The World War II concentration camp experiences of Viktor Frankl led him to develop a Kierkegaardian, existential, noetic approach to discover meaning under inhuman living conditions. We, as humans, are searching for a spiritual core to transcendence, as seen in the writings of Kierkeggard to reach beyond ourselves in the fully human dimension of the good, the true, and the beautiful in faith and in love. Special attention will be given to the lives of Patocka, Frankl, and how Kierkegaard's theology and philosophy contribute a transhistorical, phenomenological, existential, meaning-centered approach to understanding trauma, especially in the lives of returning veterans and their families.
\end{abstract}

Keywords: Kierkegaard, Frankl, Patocka, ethics, existentialism, phenomenology, noetics, trauma, veteran

The life and works of Soren Kierkegaard provide a model of attention to existential reality as an avenue to ontological transcendence of the despairs and anxiety that attend life in a postmodern world. We live in a world that gives us the freedom to make choices. Kierkegaard's epistemology creates teleology, the existential study of the end, resulting in the freedom to choose how we should live out our lives. Telos provides an opportunity to choose an end or provide guidance and direction towards an end. In the lives of Viktor Frankl and Jan Patocka, we see that such philosophy is more than theory; it becomes a living and force directed toward clear ends and goals. Frankl's philosophy allows him to transcend life in a concentration camp, and Patocka's beliefs produce the Charter 77 manifesto, a human rights document, which ultimately results in Patocka's death by the Czechoslovakian Communist secret police (Findlay, 1).

Viktor Frankl (1905-1997) was an early student of Sigmund Freud and Alfred Alder. He became a medical doctor specializing in psychiatry. After World War II, he received a Ph.D. in philosophy from the University of Vienna. In WWII, he was interred in four different concentration camps, along with his pregnant wife, parents, and siblings (V. F. Inst. of Logotherapy). Only one sister survived. He went on to write over 30 books including the classic, Man's Search for Meaning in which he describes life in the camps and lays the foundation for Logo Therapy, meaning-centered therapy. Frankl believes that even in the concentration camps, one can find meaning

Jerry L. Terrill, D.Min., LPC-S, LMFT-S, associate professor \& director of counseling, Houston Graduate School of Theology, USA; main research field: Counseling and Psychotherapy. Email: jterrill@hgst.edu. 
and choices are available. No one can take away one's inner self-worth and dignity unless one allows someone to do so. Frankl retired as a professor of psychiatry from the University of Vienna.

Jan Patocka (1907-1977) was a professor of philosophy at Charles University in Prague, and he was regarded by many people as the preeminent philosopher in Czechoslovakia (Lom, XIII). He specialized in phenomenology and studied with Edmund Husserl, Henri Bergson, and Martin Heidegger. Following World War II, Patocka refused to sign an oath of allegiance to the Communist party, and as a result, he spent the next 25 years as a file clerk. During this time, he wrote a number of books and papers, which he presented to students in underground, moveable seminars. In the early 1970s, during a "thaw" in communist politics, he returned to Charles University. There he was asked to be the tertiary head of Charter 77, a human rights document. He was one of the three key architects of Charter 77, and he became its chief spokesperson (Kohak 3). It was signed by Czechoslovakian students, intellectuals, and freedom-loving Czechs.

Soren Kierkegaard's life was a quest for the "impossible dream.” Despair and melancholy were part of his emotional development as a youth (Kierkegaard, 6). Kierkegaard's melancholy and despair were fueled, even haunted, by a fear of past failed generational initiatives. These initiatives, depressive family episodes, began with his father cursing God in his childhood while cold, lonely, and hungry, herding cattle in the harsh Danish Jutlands (12). The death of his mother and five sisters and brothers by the time he turned 21 created further depressive despair and anxiety (13). His journal detailed his broken engagement to Regina Olsen, giving vivid descriptions of his despair and grief. Kierkegaard spent pages describing his love for her even as he confronted very honestly the emotionally intense details of breaking off their engagement to become a knight of faith. Kierkegaard also suffered from what he perceived to be physical disabilities; living with a curved spine and walking with a limp caused him major negative self-esteem issues (8).

Fear and Trembling, his second major work, becomes a quest for ontological meaning. Kierkegaard beings with Phil. 2: 42's admonition that humans are to "continue to work out our salvation with fear and trembling." This passage is also found in Psalms 55: 5: "fear and trembling come upon me.” Kierkegaard believes that life provides the opportunity to grow and make choices. "The most tremendous thing which has been granted to man is: choice, freedom" (189). Frankl writes in a similar vein, "Forces beyond your control can take away everything you possess except one thing: your freedom to choose how you will respond to the situation" (Frankl, 86).

Frankl dramatically provides an illustration of this empathic and altruistic freedom of choice:

We who lived in concentration camps can remember the men who walked through the huts comforting others, giving away their last piece of bread. They may have been few in number, but they offer sufficient proof that everything can be taken from a man but one thing: the last of the human freedoms - to choose one's attitude in any given set of circumstances, to choose one’s own way. (Frankl 1992, 65-66)

Patocka writes, "Freedom thus means risk... the experience of freedom, it is true, is less common than passive experience, freedom, or better, the possibility of freedom, is something relevant to humans, as such... Freedom... is relevant and valid for all, without it a human would not be human” (Findlay, 103).

This brings us back to Abraham and his choice in freedom to live a life of faith. As Frankl puts it, "Our greatest freedom is the freedom to choose our attitude” (Frankl, 66). Derrida, quoting Kierkegaard, posits that Abraham has to make a decision to follow his faith or follow the temptation to do the right or the ethical choice (Derrida, 62). Kierkegaard speaks of faith as "the highest passion in a man. There are perhaps many in every 
generation who do not even reach it, but no one gets further... Therefore, when you were called, did you answer or did you not? Perhaps, softly and in a whisper” (Kierkegaard, Fear and Trembling, Exordium, Eulogy on Abraham)?

Kierkegaard believes that the great danger is not to take the risk. "There is a world of difference between proud courage which dares to fear the worst and the humble courage which dares to hope for the best" (192). The veteran returning from Iraq or Afghanistan fears the worst but hopes for the best. Will things be the same? Will I be able to adjust? Will my family be able to adjust? Frankl in "Man’s Search for Meaning” (1971) states, "there were two fundamental experiences that threatened to damage the character of the liberated prisoners: bitterness and disillusionment when he returned to his former life" (Frankl, 145). This opens up a world of possibilities. Kierkegaard writes, "A possibility is a hint from God. One must follow it. In every man, there is latent the highest possibility, one must follow it... Trusting to God I have found peace, calm, and confidence in God” (Kierkegaard, 147). In modern counseling theory, what Kierkegaard describes here is called "mindfulness.”

In Kierkegaard's journal, he writes about an experience on the coast of Gilbjerg.

It has always been one of my favorite places. As I stood, there was one quiet evening as the sea struck up with its song with a deep quiet solemnity, whilst my eye met not a single sail on the vast expanse of water, and the sea set bonds to the heavens, and the heavens to the sea; whilst on the other side the busy noise of life subsided and the birds sang their evening prayer... but I saw everything as a whole and was strengthened to understand things differently. (Kierkegaard 1959, 42-43)

This of course is a choice, allowing us to mindfully and experimentally view things differently. Frankl recalls going to the U.S. consulate to pick up his visa to immigrate to the United States: "then I hesitated: Should I leave my parents behind? I knew what their fate would be: deportation to a concentration camp. Should I say good-bye and leave them to their fate” (Frankl, XV)?

When he came home that day, he found his father in tears. "The Nazis have burned down the synagogue" (Frankl, XV). His father showed him a fragment of marble he had salvaged from the ruins. The piece of marble had one letter of the Ten Commandments engraved on it; Exodus 20: 11, the Fifth Commandment, "honor your father and mother." Frankl called the American embassy and canceled his visa. "It may be that I made my choice, my decision, deep within, long before, and the oracle was in reality only the echo of the voice of my conscience" (Frankl 1992, XV-XVI). Frankl, like Bonhoeffer, had the opportunity to seek safety in America but chose to remain in Vienna as an ethical—or Kierkegaardian—choice.

Jan Patocka also had an opportunity to emigrate as many of his contemporaries did; he chose to remain in Czechoslovakia. Erazim Kohak stated, “for Patocka philosophy, even at its most abstract and theoretical, was never solely abstract or theoretical. He was convinced that if the entire idea of being human-the true, the good, the just, the beautiful is to have any meaning, it must be appreciated in the act of the philosopher who stands up to bear it witness" (Lom, VI, VII). "It (philosophy) becomes an act of transcendence” (Lom, XIX). As Frankl puts it,

But what about human liberty? Is there no spiritual freedom in regard to behavior and reaction to its surroundings? Is man but an accidental product of environmental factors? The experiences of camp life show that man does have a choice of actions. Man can preserve a vestige of spiritual freedom, of independence of mind even under terrible conditions... everything can be taken away from a man but one thing: the last of human freedom to choose ones' attitudes in any given set of circumstances, to choose one's own way. (Frankl 1992, X, 86) 
Abraham is an example of a knight of faith who lives in a desert, a concrete world of reality, yet he envisions the possibility of moving beyond the limitations of the given. Patocka believes human beings have the possibility of living in the present as if it were the reality of things to come here and now ontologically. For Patocka, human striving within the real world is grounded in the vital fact of reflection; human existence is "on the way to itself, seeking itself, understanding itself, which is understanding its possibilities” (Findlay, 29). In this manner, Abraham is able to move forward in "The Binding of Isaac.” He could envision the possibilities as a knight of faith that God would intervene. This is not to say that fear and trembling, despair, and anxiety are not part of the expectancy of his faith. In his heart, Abraham is hoping for metanoia, a change of mind, and a change of heart (Carlisle, 149).

Johannes de Silentio (John the Silent), Kierkegaard's narrator, is acquainted with "suffering, life's hardships and dangers" (Carlisle, 80). Carlisle goes on to quote Jean-Paul Sartre: Abraham exemplifies the "paradoxical and humble courage of faith" (Carlisle, 156). Kierkegaard believes that human beings are temporal, always in the process of becoming "self-actualized" in Maslow’s terms (Maslow, 383). Kierkegaard is not a believer in "cheap grace." Faith limited to words is worthless. "As you have lived so you now have believed” (Vardy, 97). Frankl puts it, "Man does not behave morally for the sake of having a good conscience but for sake of a cause to which he commits himself, or for a person he loves, or for the sake of his God" (Frankl, 101-102). "He can only answer to life by answering for his life” (Frankl, 131).

This summed up in the life of Jan Patocka: "Man's calling is not so to rule but to serve... There is something higher than man, something to which human existence is indissolvably bound and without which the most basic wellsprings of our historical life dry up” (Findlay, 77). Patocka takes these words from Plato and uses them to justify the grounds for human rights protest in Charter 77, an appeal to something higher than both men and his government, something that limits man morally and reins in his desire to rule (77).

Patocka is a disciple of the ancient Greeks, who believes that man is given a soul to create a human world of truth and justice (60). "Good and evil are something to concern us... The course of our lives, Patocka contends, is determined by our pursuit of the higher movement or our capitulation to the lower" (60). This would involve sacrifice on the part of the Czechoslovakian dissidents. The light of dawn does not emerge from a void; it emerges from darkness. Darkness is a pre-condition for light to appear (Findlay, 145).

Ontology becomes the philosophy of the soul. Patocka is remembered as an anti-communist dissident who pays a Socratic price for his involvement with Charter 77. Hohak states that Patocka follows the tradition of “Czech moral humanism” (Findlay, 187). At great risk, Patocka wagers his safety in defense of his principles and chooses to participate as an architect and spokesperson for Charter 77. "Human rights are the sacred, transcendental, and absolute moral principles. This involves a commitment to freedom from ideology never in support of it” (193). Thoreau writing in Walden, agrees and confirms that compliant citizens do not attempt to transcend ideology; rather, "The mass of men lead lives of quiet desperation-there is a demand 'by the crowd' the mass of people, to live an ordinary, unexamined, and passionless life (in which God is essentially irrelevant)" (Thoreau, 9).

Kierkegaard is a great admirer of Socrates; in his journal from 1850, he writes in an essay titled "The dialectic of becoming a Christian," "Socrates did not first of all get together some proofs of the immortality of the soul in order then to live in that belief, ....and so (Socrates) lived-and his life is a proof of the immortality of the soul, his life is the proof, and only with his martyr's death is the proof complete" (Kierkegaard, 184). In 1853, Kierkegaard would write, "the mass of mankind can only relate to ideas, the good, the true, through the 
imagination" (230). The imagination becomes the starting point to a "new" you, a new normal. This means new adjustments, a different path, and a different life to be lived. This requires acceptance. Meichenbaum stresses the importance of acceptance (choice) in healing life's traumas. Marsha Linehan calls this radical acceptance openness to the here and now ontologically. The freedom of choice and acceptance allows the individual to grow existentially and philosophically even when under adverse pressure.

In the introduction to Havel's Letters to Olga (Havel's wife), a piece titled "The Last Conversation" begins:

Havel recalls that in the 1960s, Patocka would come to the Theatre on the Balustrade and hold informal discussions with actors and writers on phenomenology, existentialism and other philosophical questions. "These unofficial seminars," Havel says, "took us into the world of philosophizing in the true, original sense of the word: not the boredom of the classroom, but rather the vital search for the meaning of things and the illumination of one's self, of one's situation in the world." (Havel 1998, XVIII, XIX)

Vaclav Havel, playwright, the first president of Czechoslovakia after the downfall of communism, shares these thoughts:

As Charter spokesmen, Havel and Patocka had both been summoned to Ruzyne prison for interrogation, and during the noon break they sat in the prisoner's waiting room, discussing philosophy. "At any moment," Havel recalls, "they could have come for us, but that didn't bother Professor Patocka: in an impromptu seminar on the history of the idea of human immortality and human responsibility, he weighed his words as carefully as if we had all the time in the world ahead of us." (Havel 1998, 18-19)

Three days before he was arrested, Patocka wrote a short document called The Obligation to Resist Injustice, which attempted to explain both the motives of the Charter members, and his own motives in joining them. "The idea of human rights is nothing other than the conviction that even states, even societies as a whole, are subject to the sovereignty of ... something unconditional that is higher than they are, something that is binding even on them, sacred, inviolable. "There are things for which it is worthwhile to suffer.” (Kohak 1989, 340, 346)

The calmness of Prof. Patocka in the waiting room reminds us of a Buddhist Zen story, which characterizes life as a Buddhist monk fleeing from a hungry tiger. The monk comes to the edge of a cliff, and fortunately a vine happens to be growing over the edge. He grabs hold of it and begins to climb down the cliff, out of the tiger's reach, which is by now glaring at him from above. But alas, as the monk descends, he spies another tiger waiting for him below, circling impatiently at the bottom of the cliff. To make matters worse, he notices a mouse on a ledge above him already beginning to gnaw through the vine. Then out of the corner of his eye, the monk sees a strawberry growing from the rock. So he picks the strawberry and eats it (Hesselink).

On March 13, 1977, Patocka died of a brain hemorrhage after a brutal eleven-hour "interrogation" by the Czechoslovakian Communist secret police in Prague (Kohak, 3).

Kierkegaard, in Fear and Trembling, comes to terms with despair and doubt as seen through the life of Abraham. He provides a philosophy that comes to impact Drs. Frankl and Patocka, even until death. His writings and those of Dr. Frankl and Dr. Patocka provide a core philosophy in counseling with veterans suffering from the trauma of war and their families. It provides hope to individuals suffering from suicidal ideation and matters of faith. Kierkegaard has written a necessarily philosophical faith work that transcends the centuries. 


\section{Works Cited}

Carlisle, Clare. Kierkegaard's Fear and Trembling. London: Continuum International Publishing Group, 2010.

Derrida, Jacques. The Gift of Death and Literature in Secret. Trans., David Wills. Chicago: University of Chicago Press, 2008. Findlay, Edward. Caring for the Soul in a Postmodern Age. Albany: State University of New York Press, 2002.

Frankl, Viktor. Man’s Search for Meaning. New York: Pocketbooks, 1984 \& 1992.

Havel, Vaclav. Letters to Olga. Trans., Paul Wilson. New York: Alfred A. Knopf, 1988.

Kohak, Erazim. Jan Patocka: Philosophy and Selected Writings. Chicago: University of Chicago Press. 1989.

Kierkegaard, Soren. The Journals of Kierkegaard. Trans., Alexander Dru. New York: Harper Torch Books, 1959.

---. Fear and Trembling. Trans., Alastair Hanny. London: Penguin Books, 1985.

Patocka, Jan. Body, Community, Language, World. Trans., Erazim Kohak. Chicago: Open Court Publishing Company, 1998.

---. Heretical Essays in The Philosophy of History. Trans., Erazim Kohak. Chicago: Open Court Publishing Company, 1996.

---. Jan Patocka: Philosophy and Selected Writings. Trans., Erazim Kohak. Chicago: University of Chicago Press, 1989.

---. Plato and Europe. Trans., Petr Lom. Standford: Standford University Press, 2002.

Thoreau, Henry David. Walden and Other Writings. New York: Bantam Dell, 1981.

Vardy Peter. An Introduction to Kierkegaard. Peabody: Hendrickson Publishers, Inc., 2008. 